Ogneupour. Prom., 42, 115-24 (1971) (Chem. Abst., 76-75935 m (1971)).

\title{
$\mathrm{CaO}-\mathrm{SiO}_{2}$ 系の水熱反応における原料石英の 磨砕処理の影響
}

\author{
東 保男・末 廣建 介 \\ (東海大学 工学部 工業化学料)
}

\begin{abstract}
原料である石英の磨研処理が $\mathrm{CaO}-\mathrm{SiO}_{2}$ 系の水熱反応にどのように影響するかを小型反応容器を オイルバス中に入れ反応温度を速やかに上げる方法で検討した.

石英の磨砕処理により反応性は向上するが，24 時間磨砕の場合は 3 時間以後に著しい反応の遅 延を認めた. また生成物の $\mathrm{CaO} / \mathrm{SiO}_{2}$ の組成比, $(1-\sqrt[3]{1-\alpha})^{N}=k t の N$ 值, 生成物の形態等は, 原料の石英の磨砕処理により変化することを認めた.

以上の結果は，石英の磨砕処理によって反応機構が異なることを示唆している．この理由は，磨 砕によって生じた無定形シリカが速やかに反応し, 初期段階でち密化された反应層が形成され, そ のために溶解, 拡散が困難になり反応機構に違いが生じるし, また反応の遅娫も起こると考えられ る. すなわち, $\mathrm{CaO}-\mathrm{SiO}_{2}$ 系の水熱反応は原料である石英中の無定形シリカの影響を評価すべきで あると考えた.

（昭和 57 年 4 月 5 日受付）
\end{abstract}

\section{Effect of Grinding of Raw Quartz on the Hydrothermal Reaction in $\mathrm{CaO}-\mathrm{SiO}_{2}$ System}

\author{
Yasuo AZUMA and Kensuke SUEHIRO \\ (Department of Industrial Chemistry, School of Engineering, Tokai University) \\ 1117, Kitakaname, Hiratsuka-shi 259-12
}

The effect of grinding of raw quartz on the hydrothermal reaction in $\mathrm{CaO}-\mathrm{SiO}_{2}$ system was investigated by using a small reaction vessel immersed in oil bath for rapid heating. Results obtained were as follows.

(1) It was found that reaction is generally accelerated by grinding, but that prolonged grinding retarded the reaction, especially, in the case of so long-time grinding as $24 \mathrm{~h}$, reaction hardly proceeded after $3 \mathrm{~h}$.

(2) The molar ratio $\left(\mathrm{CaO} / \mathrm{SiO}_{2}\right)$ of the reacted composites was changed from 4.1 to 1.6 for unground quartz, and 0.3 to 1.9 for ground quartz.

(3) It was found that $N$ value of the equation, $(1-\sqrt[3]{1-\alpha})^{N}=k t$, was $1.3 \sim 2$ for raw quartz, and larger than 2 for ground quartz.

(4) Ca-ion concentration in water exceeded greatly than that of silicic acid after reaction.

(5) From the results of X-ray and TG-DTA analyses, C-S-H was the only compound formed, but the textures of the hydrates were very different from each other, namely, plate or needle crystals were observed for unground quartz, and long fibrous crystals were observed for ground quartz.

From these results, it was found that the reaction took place in a different mechanism by grinding treatment, and especially, the reaction with long-time ground quartz nearly stopped in a half way. This seems likely to be due to the fact that amorphous silica produced on the surface of the ground quartz reacted rapidly, and the further reaction was inhibited by 
the dense layer produced in its initial stage. Therefore, the influence of amorphous silica in quartz should be taken into accout on the hydrothermal reaction in $\mathrm{CaO}-\mathrm{SiO}_{2}$ system.

[Received April 5, 1982]

Key-words : Ground quartz, $\mathrm{CaO}-\mathrm{SiO}_{2}-\mathrm{H}_{2} \mathrm{O}$, Reaction rate, $\mathrm{CaO} / \mathrm{SiO}_{2}$ ratio, Texture

\section{1. 緒言}

原料の石英を磨砕すると粉砕と同時に無定形化が起こ ることが知られている1). しかし，この無定形シリカ量 の測定法に問題があることを既報2で指摘した.

一方, 従来の $\mathrm{CaO}-\mathrm{SiO}_{2}$ 系の水熱反応の研究では, 石 英の種類, 粒度, 配合比の影響について詳しい報告8) 13) がある.しかし，磨砕によって石英が微粉体になるに従 って生じる無定形シリカの影響を評価したものは見当た らないようである.

そこで本研究では, 石英を各時間磨砕し, 水熱反応に どのように影響するかを検討した. また，従来の大型オ ートクレーブは所定温度に達するのにかなりの時間を要 するので，本実験ではこの昇温時間の影響をできるだけ 減少するため小型の反応容器を作製し, 所定温度のオイ ルバス中に入れて数分間で所定温度に昇温させる方法に 改めた結果, 初期反応がより明確になるのではないかと 期待し検討を加えることにした.

\section{2. 実験}

\section{1 試 料}

原料の水酸化カルシウムは市販品特級で純度 $96 \%$ で ある． $\alpha$-石英は既報2 の試料を用いたが，原料の石英の 平均粓径は $24 \mu \mathrm{m}$ であり, 磨砕はメノウ製の石川式ら いかい機を用い，1，6，24 時間行った試料を用いること にした. この石英の物性値は既報2)に記載したので省略 する.

\section{2 試料の混合, 水熱反応の条件}

$\mathrm{CaO} / \mathrm{SiO}_{2}$ の混合比はモル比で $1 / 1$ とし, 混合は小型 のボールミルを用い，エチルアルコール添加による湿式 混合である. 混合後, 減圧乾燥によってエチルアルコー ルを除去した. この試料を成形圧 $100 \mathrm{~kg} / \mathrm{cm}^{2}$ で錠郕 $(10 \mathrm{~mm} \phi$, 厚さ $3 \mathrm{~mm})$ にして反応に使用した.

小型オートクレーブ $(15 \mathrm{~mm} \phi)$ の内容積は $17 \mathrm{ml}$ で, 添加水量は $10 \mathrm{ml}$ である. 加熱はオイルバスを用い， 反 応温度を $140^{\circ} \mathrm{C}, 180^{\circ} \mathrm{C}$ に設定した. 反応後, 錠郕をア セトンに入れて反応を止め, 更に粉末にした後減圧乾燥 し次の諸試験の試料とした.

\section{3 末反応石灰, 石英量の測定法}

試料中の未反応石灰量は Franke 法年)で行ったが, TG-DTA の分析結果, $3 \%$ 前後の炭酸カルシウムの混 入が認められたので, この分析值より炭酸カルシウム 量を求め, 未反応石灰量を補正した. 未反応石英量は
Steopoe 法の改良法 ${ }^{10)}$ で測定した. なお，加熱減量は $900^{\circ} \mathrm{C}, 30$ 分間で行った.

また, 反応直後の水相の $\mathrm{pH}$ ，カルシウムイオン，ケ イ酸イオンの濃度を調べた. すなわち, カルシウムイオ ンは EDTA 法 ${ }^{15)}$ ，ケイ酸イオンはモリブデン法 ${ }^{16)} に よ$ って測定した.

TG-DTA 装置は理学電機社製で比較試料 : $\alpha-\mathrm{Al}_{2} \mathrm{O}_{3}$, 昇温速度 : $10^{\circ} \mathrm{C} / \mathrm{min}$, 感度 : $\pm 50 \mu \mathrm{V}$ で使用した.

走查型電子顕微鏡 (SEM) 装置 は島津作製所製であ る.

\section{3. 結果及び考察}

\section{1 末反応石灰, 石英量の測定結果}

石英の磨砕処理が水熱反応性にどのような影響を与え

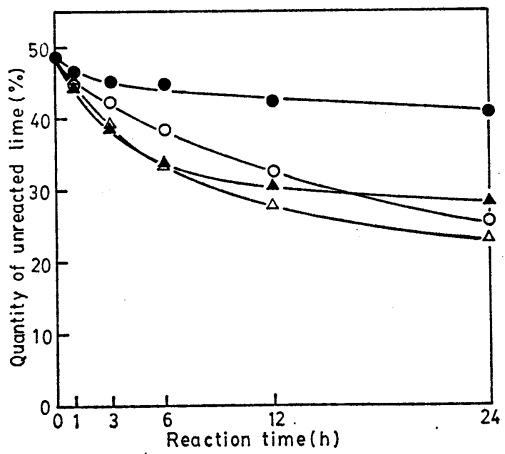

Fig. 1. Relationship between quantity of unreacted lime and reaction time at $140^{\circ} \mathrm{C}$.

Samples; : Original, $\bigcirc$ : Ground for $1 \mathrm{~h}$, $\triangle:$ Ground for $6 \mathrm{~h}, \boldsymbol{\Delta}:$ Ground for $24 \mathrm{~h}$

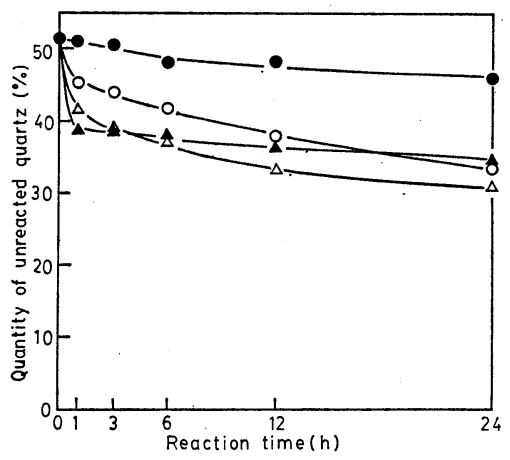

Fig. 2. Relationship between quantity of unreacted quartz and reaction time at $140^{\circ} \mathrm{C}$.

Samples; : Original, $\bigcirc$ : Ground for $1 \mathrm{~h}$, $\triangle:$ Ground for $6 \mathrm{~h}, \boldsymbol{\Delta}:$ Ground for $24 \mathrm{~h}$ 


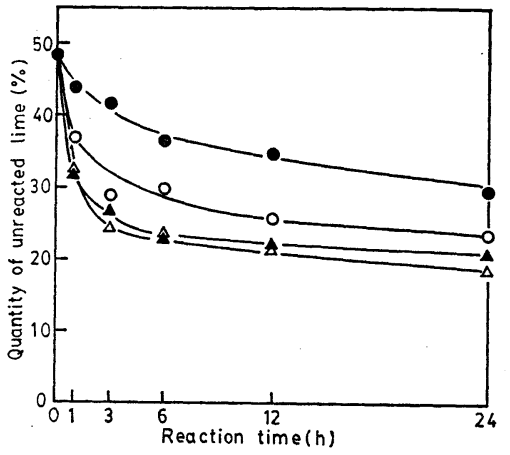

Fig. 3. Relationship between quantity of unreacted lime and reaction time at $180^{\circ} \mathrm{C}$.

Samples; : Original, $\bigcirc:$ Ground for $1 \mathrm{~h}$, $\triangle:$ Ground for $6 \mathrm{~h}, \Delta:$ Ground for $24 \mathrm{~h}$

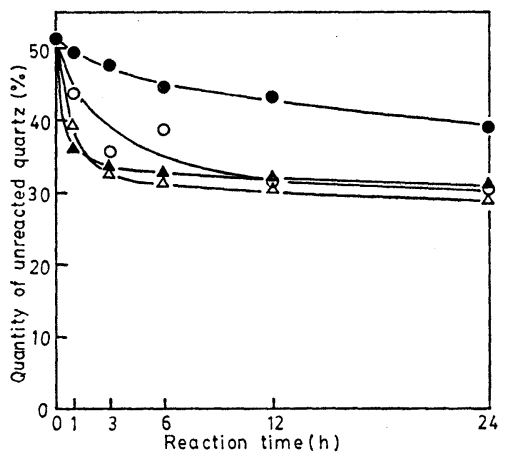

Fig. 4. Relationship between quantity of unreacted quartz and reaction time at $180^{\circ} \mathrm{C}$.

Samples; : Original, $\bigcirc:$ Ground for $1 \mathrm{~h}$,

$\triangle:$ Ground for $6 \mathrm{~h}, \boldsymbol{\Delta}:$ Ground for $24 \mathrm{~h}$

るかを調べるために，まず未反応石灰及び石英量を測定 した. その結果は図 1, 2, 3 及び 4 に示す. 未反応石灰， 石英量はいずれの場合でもほぼ同様な傾向で減少し，減 少量は $180^{\circ} \mathrm{C}$ の場合では当然 $140^{\circ} \mathrm{C}$ より大きが, 近 藤ら ${ }^{6)}$, 光田ら ${ }^{5}$ が報告した反応率より小さい值を示 した.この理由として原料石英の粒度の差が考えられる が, そのほかに実験方法の相違が考えられる.すなわち， 光田らの実験は懸濁法であり, 近藤らは大型のオートク レーブを用いているので, 所定温度に到達するのにかな りの時間を必要とし，その間に反応は進行するが，本実 験では 1 章で述べたように小型の反応容器をオイルバス 中で加熱したため温度が急速に上がり, 反応が急激に起 こったためと考えられる.

一方，石英の反応性は未磨砕に比較して 1 時間の初期 反応では磨砕時間とともに良くなることが認められる が, 24 時閒磨砕した場合, 3 時間反応以後反応は停滞す るのが見られた.

次に未反応石灰, 石英量の測定結果より生成物の組成 比 $\left(\mathrm{CaO} / \mathrm{SiO}_{2}\right.$ のモル比，以下 $\mathrm{C} / \mathrm{S}$ と略記する）を算出 し，その結果を表1 に示す. 未磨砕の C/S は 4.1 1.6
Table 1. The molar ratio $\mathrm{CaO} / \mathrm{SiO}_{2}$ in combined calcium silicate.

\begin{tabular}{l|c|cccc}
\hline Temp. & R. T. & \multicolumn{4}{|c}{ CaO/ $\mathrm{SiO}_{2}$ (molar ratio) } \\
\cline { 3 - 6 }$\left({ }^{\circ} \mathrm{C}\right)$ & $(\mathrm{h})$ & Original & $G .1 \mathrm{~h}$ & $6.6 \mathrm{~h}$ & $\mathrm{G.24h}$ \\
\hline & 1 & 4.1 & 0.6 & 0.3 & 0.5 \\
140 & 3 & 3.7 & 0.8 & 0.5 & 0.8 \\
& 6 & 1.1 & 1.1 & 0.9 & 1.2 \\
& 12 & 1.7 & 1.1 & 1.0 & 1.2 \\
& 24 & 1.3 & 1.3 & 1.3 & 1.3 \\
\hline \multirow{4}{*}{180} & 1 & 2.1 & 1.5 & 1.3 & 1.1 \\
& 3 & 1.9 & 1.3 & 1.3 & 1.3 \\
& 6 & 1.8 & 1.7 & 1.3 & 1.4 \\
& 12 & 1.8 & 1.3 & 1.3 & 1.4 \\
& 24 & 1.6 & 1.3 & 1.4 & 1.4 \\
\hline
\end{tabular}

の大きな值を取るが，磨砕した場合は $0.3 〜 1.7$ の範囲 の值である. また未磨砕の場合では $\mathrm{C} / \mathrm{S}$ は反応時間と ともに下がるが，磨砕した試料では明らかに反応時間と ともに C/S 值が上がり, 1.3 前後の值を取ることを認め た. 著者 ${ }^{17)}$, 光田 $ら^{5)}$, 近藤 $ら^{6)}, \mathrm{Kalousek}^{7)}$ は石英を原 料とした場合の初期生成物を高石灰組成である $\alpha-\mathrm{C}_{2} \mathrm{SH}$ であるとしている．本実験の未磨砕での生成物は X線回 折で $\alpha-\mathrm{C}_{2} \mathrm{SH}$ を確認できないが, 分析結果では高石灰組 成であることを認めた. 一方，磨砕した場合では，まず 低石灰組成物が生成し高石灰組成物へと変化した. この 組成の変化は近藤ら ${ }^{10)}$ が報告した無定形シリカを原料と した場合と同じである.

\section{2 反応速度式による検討}

反応速度の検討は 近藤 $\left.{ }^{6}\right)$ が示した $(1-\sqrt[3]{1-\alpha})^{N}=k t$ の式で行った. その結果を図 5 及び 6 に示す. ただし， 反応率 $(\alpha)$ は末反応石灰, 石英量より算出した. その 結果, 未磨砕の場合では, 直線であり反応速度式が全領

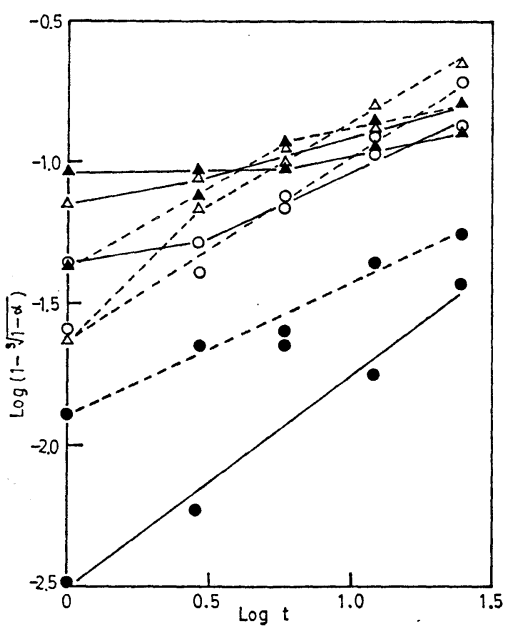

Fig. 5. Plots of $\log (1-\sqrt[3]{1-\alpha})$ vs. $\log t$ at $140^{\circ} \mathrm{C}$.

Samples; : Original, $\bigcirc:$ Ground for $1 \mathrm{~h}$, $\triangle:$ Ground for $6 \mathrm{~h}, \boldsymbol{\Delta}:$ Ground for $24 \mathrm{~h}$ (.... : Lime, - : Quartz) 


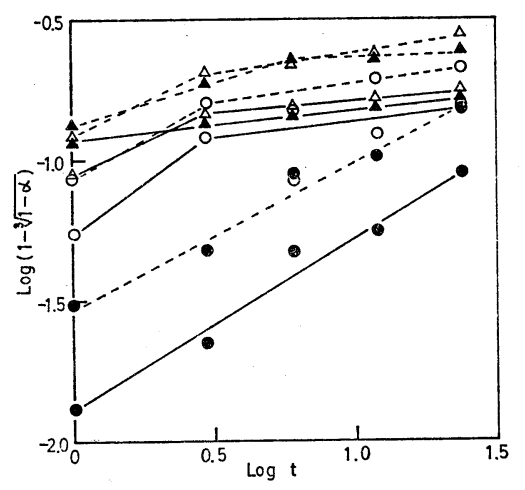

Fig. 6. Plots of $\log (1-\sqrt[3]{1-\alpha})$ vs. $\log t$ at $180^{\circ} \mathrm{C}$.

Samples; : Original, $\bigcirc:$ Ground for $1 \mathrm{~h}$, $\triangle:$ Ground for $6 \mathrm{~h}, \boldsymbol{\Delta}:$ Ground for $24 \mathrm{~h}$ (...: : Lime, - : Quartz)

域に適用できるが，磨砕した場合では，直線が折れる傾 向を示した. 特に $180^{\circ} \mathrm{C}$ の場合では直線が 3 時間反応か ら折れ曲がる.この事実は石英を磨确処理すると反応機 構が異なることを示唆している.

また，速度式の $N$ 值を求めると未磨研の場合では 1.3 2.0 であり，反応律速は抬散であることが推定で きる. $140^{\circ} \mathrm{C}$ の 1,6 時閒磨䃏した場合の $N$ 值は, 石 灰で $1.0 ， 1.5 ， 2.0$ であり, 石英では 2 以上の值であ る. $180^{\circ} \mathrm{C}$ の場合では初期の $N$ 值は 2 前後であるが, 3 時間反応以後では $N$ 值は $N>2$ である. 特に 24 時 間磨砕した場合では, 石英で 1 時間反応から $N>2$ で あった。 この $N$ 值は近藤ら ${ }^{6)}$ が報告した石灰で 1 , 石英 で 2 前後の值であるとしていることと異なった. 前述の ように本実験では反応温度を短時間に上げたため, 反応 が表面で急速に起こり, 表面層を形成し, 更に $N>2$ で あることから反応層はち密化されて, 水酸カルシウム, ケイ酸の溶解，拡散が困難になったと考えられる.ま た, 24 時間磨砕した石英の場合では, 特に $N$ 值が大き 、值を示すことより反応層の一層のち密化が起こり，そ のため反応の遅延が生じるものと考えられる.

更に $N>2$ になる理由として, 石英を磨砕処理すると 無定形シリカが形成され，この無定形化された部分は活 性で速やかに水に溶解し, カルシウムと反応し, ち密な 反応層を形成するものと考えられる.また，著者ら ${ }^{187}$ は シリカゲルを用いた水熱反応において反応の遅延を認め ている. 本実験でも同様な現象が認められるが，上述の ように石英中の無定形シリカが速やかに反応し, 反応層 の形成が起こり, 以後の反応を妨げるものと考えれば説 明できる.

\section{3 反応率と比表面積, 無定形シリカ量の関係}

初期反応 (1 時間反応) の反応率 $(\alpha)$ と先に報告 ${ }^{2)}$ した試料石英の比表面積及び磨砕によって生じた無定形

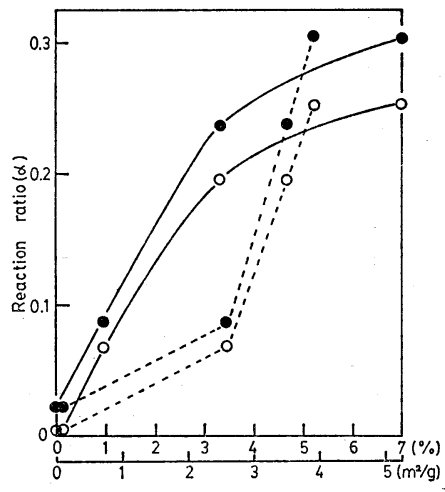

Fig. 7. Reaction ratio (quartz) vs. surface area or amorphous silica content after one hour reaction.

Temperature; $\bigcirc: 140^{\circ} \mathrm{C}, 180^{\circ} \mathrm{C}$

(…: Surface area, - : Amorphous silica content)

シリカ量の值（アルカリ溶解法で求めた值）をプロット し，その結果を図 7 に示す.

石英の比表面積は 1 時間磨砕で急激に増大するが，そ の後は徐々にしか堌加しないことを認めている。一方， 反応率は磨砕処理すると急激に高くなる. しかも，無定 形シリカ量に対して比例して高くなる傾向がある.すな わち，石英の反応性は単に比表面積（粒度）に比例する のではなく，明らかに無定形シリカが初期反応に影響す るものと推定できる.

\section{4 反応直後の水相の $\mathrm{pH}$ ，カルシウムイオン， ケ イ酸イオン濃度}

反応液の $\mathrm{pH}$ 值は $12 \sim 13$ の範囲であったが，反応条 件との関係は認めることはできなかった.

カルシウムイオン, ケイ酸イオン濃度の測定結果を表 2 に示す. 測定值にかなりの相異があるが，相対的に考 えてカルシウムイオンはケイ酸イオンより非常に過剩 であった.この事実はケイ酸の溶解，拡散が反応を支配 していることを示唆していると考えられる.

\subsection{TG-DTA, SEM による生成物の検討}

Table 2. Concentration of $\mathrm{CaO}$ and $\mathrm{SiO}_{2}$ dissolved in water after reaction.

\begin{tabular}{|c|c|c|c|c|c|c|c|c|c|}
\hline \multirow{3}{*}{$\begin{array}{l}\text { Temp } \\
\left({ }^{\circ} \mathrm{C}\right)\end{array}$} & \multirow{3}{*}{$\begin{array}{l}\text { R.T. } \\
\text { (h) }\end{array}$} & \multicolumn{8}{|c|}{$\mathrm{CaO}, \mathrm{SiO}_{2}$ concentration $(\mathrm{mg} / \mathrm{l})$} \\
\hline & & \multicolumn{2}{|c|}{ Original } & \multicolumn{2}{|c|}{ G.1h } & \multicolumn{2}{|c|}{$G .6 \mathrm{~h}$} & \multicolumn{2}{|c|}{ G.24h } \\
\hline & & $\mathrm{CaO}$ & $\mathrm{SiO}_{2}$ & $\mathrm{CaO}$ & $\mathrm{SiO}_{2}$ & $\mathrm{CaO}$ & $\mathrm{SiO}_{2}$ & $\mathrm{CaO}$ & $\mathrm{Si} \mathrm{O}_{2}$ \\
\hline \multirow{5}{*}{140} & 1 & 570 & 5.4 & 320 & 4.2 & 450 & 4.5 & 380 & 1.4 \\
\hline & 3 & & 5.8 & 90 & 4.1 & 00 & 4.6 & 70 & 0.8 \\
\hline & 6 & 360 & 4.1 & 340 & 4.1 & 320 & 5.0 & 390 & 0.8 \\
\hline & 12 & 420 & 4.1 & 330 & 4.2 & 200 & 7.0 & 380 & 0.8 \\
\hline & 24 & 350 & 4.1 & 280 & 4.2 & 240 & 7.0 & 260 & 0.8 \\
\hline \multirow{5}{*}{180} & 1 & 220 & 4.6 & 250 & 5.8 & 190 & 5.0 & 140 & 5.8 \\
\hline & 3 & & 4.2 & 170 & 5.8 & 180 & 5.0 & 130 & 5.0 \\
\hline & 6 & 250 & - & 200 & 5.8 & 170 & 2.5 & 180 & 5.8 \\
\hline & 12 & 26 & 5.8 & 230 & 5.0 & 2.30 & 2.5 & 150 & 1.7 \\
\hline & 24 & 290 & 2.1 & 210 & 5.8 & 260 & 2.5 & 210 & 2.5 \\
\hline
\end{tabular}


生成物をX線回折で調べたが，未反応の水酸化カルシ ウム, 不英の回折線と生成物の回折線は単に $d=3.02 \AA$ に現れるだけであった. そこで TG-DTA により検討 してみた.その結果を図8及び 9 に示す.

$400^{\circ} \mathrm{C}$ 以下の重量減少となだらかな吸熱ピークは付着

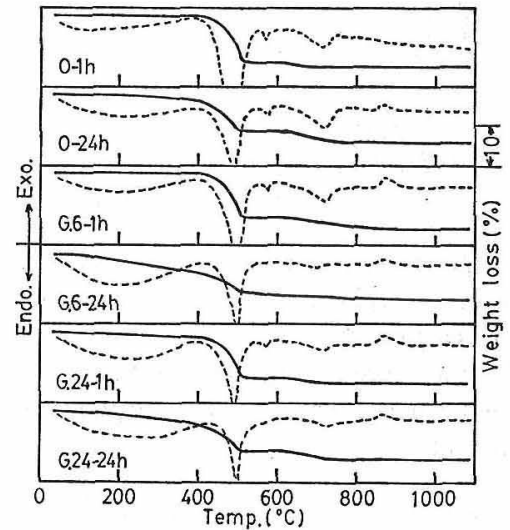

Fig. 8. TG-DTA curves for specimens at $140^{\circ} \mathrm{C}$.

(一 : TGA, -... : DTA)

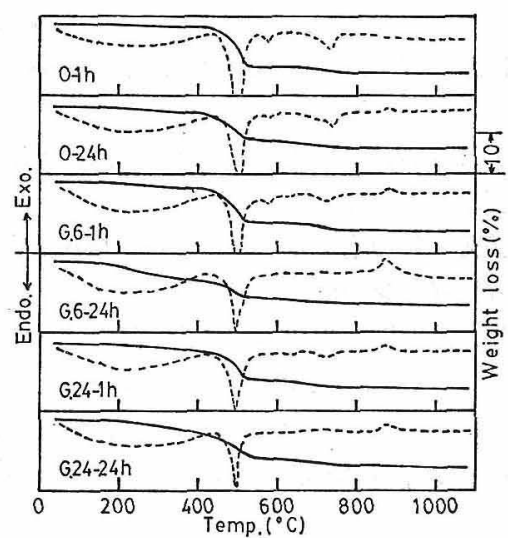

Fig. 9. TG-DTA curves for specimens at $180^{\circ} \mathrm{C}$.

(一: TGA, ...: : DTA)

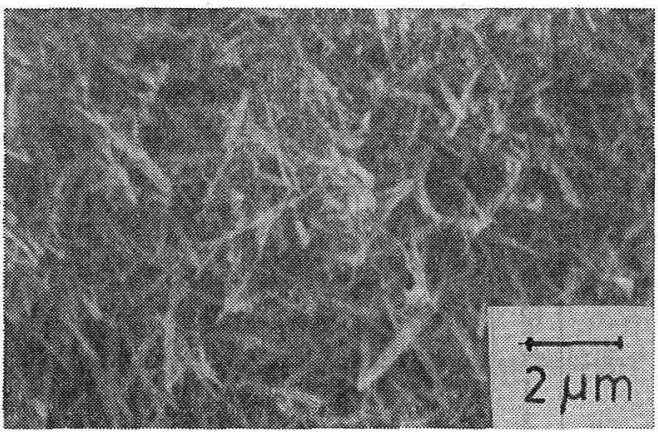

(a)
水と C-S-H の脱水により生じたと考えられるし, $500^{\circ} \mathrm{C}$ 付近の鋭い吸熱ピークは未反応の水酸化カルシウムの脱 水に相当する。 また $570^{\circ} \mathrm{C}$ のさい吸熱ピークは石英の low-high 転移熱である. $720^{\circ} \mathrm{C}$ 付近の $3 \%$ 前後の重 量減少と吸熱ピークは炭酸カルシウムによることが判明 したので，1.2 節で述べたよらに未反応石灰值をこの結 果より補正した. 次の $830^{\circ} \sim 870^{\circ} \mathrm{C}$ の発熱ピークはケイ 灰不への再結晶化熱に相当すると言われている ${ }^{12)}$.この 生成物の TG-DTA 曲線は光田ら ${ }^{19}$ の報告したトバモ ライトによく似たものであった。

訊料の破断面を走查型電子顕微鏡 (SEM) で観察し た. その結果を図 10 に示す. 未磨砕の $180^{\circ} \mathrm{C}, 24$ 時間 反応（図 10 (a)）では，生成物の形態は短冊状あるい は針状のようなものである. 磨砕した場合（図 10 (b)） での形態はよく伸びた繊維状である.TG-DTA，X線回 折の分析結果では, 生成物にほとんど相異がないにもか かわらず，その形態は異なっていた.

一方, 試料の破断面の写真において 3.2 節で述べた ら密化された反店を署いだすことはできない.しか し，磨砕した石英の反応は図 6 のように折点をもつ2 段 階反応であり，反応の初期において磨哗石英表面の無定 形層が速やかに反応して界面に C-S-H の微結晶層が形 成される.この反応生成物層は薄いがち密であるため, 第 2 段の反応はケイ酸イオンの拡散律速となる. そして 結晶は初期反応生成物層の微結晶を核として, ケイ酸イ オンの供給に従って徐々に成長して繊維状形態をとるよ うになるものと考えられる. また，未処理の石英を用い た場合は反応の進行が遅く，またその表面に核となる点 も少なくないので結晶は徐々に成長し, 比較的よく発達 した板状あるいは針状の形態をとるものと考える。

\section{4. 総 括}

石英の磨砕処理が $\mathrm{CaO}-\mathrm{SiO}_{2}$ 系の水熱反応にどのよう に影響するかを調べた. ことに初期反応を検討するため に実験は小型反応容器を用い，反応温度を速やかに上げ

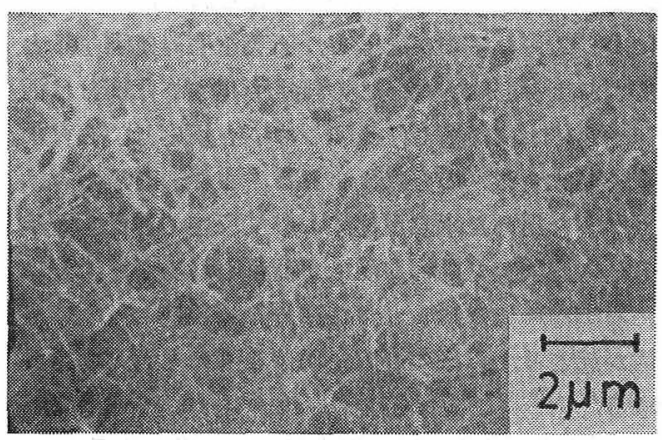

(b)

Fig. 10. SEM micrograph of products. Hydrothermal reaction; $180^{\circ} \mathrm{C}, 24 \mathrm{~h}$. (a) : Raw quartz, (b) : Ground for $24 \mathrm{~h}$. 
る方法を採用した. その結果，次のことが分った.

石英の磨砕により反応性は向上するが，24 時間磨砕 した石英の場合は 3 時間以後に著しい反応の遅延を認め た. また C/S の組成比は未磨砕で 4.1〜1.6 であり, 磨砕の場合は 0.3 1.7 の範囲で変化した. 反応速度式 の $N$ 值は未磨砕で $1.3 \sim 2.0$ であるが, 磨砕では $N>2$ の值を取る傾向がある. 生成物は TG-DTA，X線によ ると C-S-H であるが, その生成物の形態は未磨砕と磨 砕の場合とでは異なっていた.

以上の結果は, 石英の磨砕処理によって反応機構が異 なることを示唆している. この理由は, 磨砕によって生 じた無定形シリカが速やかに反応し, 初期段階でち密化 された反応層が形成され，そのために溶解，拡散が困難 になり，反応機構に違いが生じたと考えられるし，また 反応の遅延む起こると考えられる.すなわち, $\mathrm{CaO}-\mathrm{SiO}_{2}$ 系の水熱反応は原料である石英中の無定形シリカの影響 を評価すべきであると考えた.

本研究は昭和 56 年窯業協会年会で発表したものである.

\section{文献}

1）久保輝一郎, “メカノケミストリー概論”, 第 2 版, 東京 化学同人 (1978) p. 63-73.

2）東 保男, 末廣建介, 窵協, 87, 597-602 (1979).
3）竹本国博, 窯協, 73, 91-97 (1965).

4）詹前鋒, 光田 武, セメント技術年報, 30, 41-44 (1976).

5）石井隆生，詹 前鋒，光田 武，セメント技術年報， 32， 75-77 (1978).

6）近藤連一, 李 卿喜, 大門正機, 窯協, 84, 573-78 (1976).

7) G.L. Kalousek, J. Am. Coner. Inst., 989-1011 (1954).

8) G.L. Kalousek, J.S. Logiudice and V.H. Dodson, $J$. Am. Ceram. Soc., 37, 7-12 (1954).

9) C.F. Chan and T. Mitsuda, Cement. Concr. Res., 8, 135-38 (1978).

10) 近藤連一, 大沢栄一, 松丸 裕, 北村 勝, 加藤高明, セメント技術年報，21，92-100 (1967).

11) A. Aitken and H.F.W. Taylor, J. Appl. Chem., 10, 7-15 (1960).

12）関谷卓三, 前田良平, 森口基十雄, セメント技術年報, 20, 60-67 (1966).

13) R. Kondo, S.A. Abo-El-Enein and M. Daimon, Bull. Chem. Soc. Jpn., 48, 222-26 (1975).

14) E.E. Presser, S. Bronaer and D.L. Kantro, Anal. Chem., 5, 896-902 (1956).

15）高木誠司，“定量分析の実験々計算，容量分析法”，共立 出版 (1975) p. 329

16）日本分析化学会編, “分析化学便覧”, 丸善 (1961) p. 444.

17) 東 保男, 末廣建介, 東海大学紀要工学部, No. 2, 9196 (1978).

18）東 保男, 磯部悦男, 伊藤英男, 末廣建介, 日化, 1975, 826-30.

19) T. Mitsuda and H.F.W. Taylor, Mineral. Mag., 42, 229-35 (1978).

\title{
分子動カ学法によるハロゲン化物ガラスの物性と構造
}

\author{
平尾一之・曾 我直弘 \\ (京都大学 工学部 工業化学科)
}

ガラスの物性と構造の関係を求めるためにイオンポテンシャルを仮定してハロゲン化物ガラスの 分子動力学計算を行った. 本研究では特に $\mathrm{AgI}$ と $\mathrm{ZnCl}_{2}$ の融液及びガラスのシミュレーション の結果を示した. AgI ガラスと融液の構造は, 2 体相関関数 $g_{2}(r)$ を用いて表したが, 同種イオ ン閒の第 1 ピークが分裂すること, $\mathrm{Ag}^{+}$は I- に比べて秩序が悪いことなどが明らかになった。 た，これらのイオンの動きを直接見るために， $X-Y, Y-Z$ 平面に投影した軌跡図を用いて検討し た. 更に, これらの計算を挔張して, エンタルピー, 体積, 拡散係数等を求め, 温度の関数として 表した. その結果, ガラス転移温度付近でこれらの物性に変化がみられた. 上記の計算を実験室で 実際にガラス化可能な $\mathrm{ZnCl}_{2}$ に応用した結果，シミュレーションにより合成したガラスの物性と 実験值とはよく対応しており, 本質的な差は認められなかった. 以上より, 分子動力学法をハロゲ ン化物ガラスに適用することにより，元素の違いによるガラスの物性及び構造の変化を予測するこ とが可能であると思われた.

(1982 年 5 月 28 日受付) 